\title{
EKSISTENSI BUDAYA PATRON KLIEN DALAM PESANTREN: Studi Hubungan Antara Kiai dan Santri
}

\author{
Eko Setiawan \\ Fakultas Pertanian Universitas Brawijaya Malang Jl. Veteran, Malang 65145, \\ Indonesia, Telp: 085755597774 email: oke.setia@gmail.com
}

\begin{abstract}
Abstrak
Penelitian ini bertujuan untuk mengetahui bagaimana gambaran pola interaksi hubungan sosial Kiai dan santri, untuk mengetahui bentuk perubahan pola interaksi hubungan sosial yang terjadi antara Kiai dan santri setelah adanya modernisasi dalam kurun waktu 2005-2012, untuk mengetahui faktor-faktor apa saja yang menyebabkan budaya patron klien dapat bertahan sampai sekarang. Penelitian ini adalah penelitian kualitatif dengan menggunakan model studi kasus. Penelitian ini berusaha untuk memahami makna budaya patron klien tentang hubungan Kiai dan santri. Pola hubungan Kiai dan santri dapat dipahami menggunakan orientasi teoritik atau perspektif teoritik dengan pendekatan fenomenologis. Lokasi penelitian terletak di Pondok Pesantren Daarul Fikri Mulyoagung Dau Malang. Pesantren Daarul Fikri merupakan suatu lembaga independen yang tidak berafiliasi kepada organisasi atau golongan manapun. Hal ini menjadikan Daarul Fikri sebagai lembaga pendidikan yang mengedepankan kemurnian dan idealisme pendidikan yang terbebas dari kepentingan politik maupun golongan tertentu.
\end{abstract}

This study aims to determine how the image of social interaction patterns Kiai and santri, to know the form of the changing patterns of social interaction that occurs between the Kiai and santri after the modernization in the period 2005-2012, to determine what factors are causing cultural patron clients are able to survive until now. This is a qualitative research which uses a case study model. This study seeks to understand the cultural significance of patron-client relationships Kiai and santri. To understand the meaning of relationships between Kiai and santri, this study uses theoretical orientation or theoretical 
perspective with a phenomenological approach. The location of this research is in Pondok Pesantren Daarul Fikri Mulyoagung Dau Malang. Pondok Pesantren Daarul Fikri is an independent institution not affiliated to any organization or group. This makes Pondok Pesantren Daarul Fikri as educational institutions that promotes educational ideals of purity and free from political interests or certain groups.

Key words: patron client, pesantren, Kiai, santri

\section{Pendahuluan}

Arus modernisasi dewasa ini disadari ataupun tidak telah membawa berbagai macam perubahan hampir di semua lini kehidupan. Salah satu perubahan konkrit adalah gencarnya penetrasi teknologi yang semakin memungkinkan manusia menjadi lebih mudah melakukan aktivitas sehari-hari. Teknologi seperti halnya alat komunikasi telah mampu mengubah persepsi masyarakat akan batas-batas ruang teritorial yang selama ini dianggap hampir tak terjangkau. Pada sisi yang lain, modernisasi juga telah secara pelan tapi pasti mengubah kultur lokal menjadi lebih terbuka dengan mengikuti perubahan yang terjadi. Pada titik ini, budaya lokal yang dianggap sakral oleh masyarakat dan selalu dijadikan pijakan dalam setiap tindakannya lambat laun mengalami pergeseran. Pesantren sebagai lembaga Islam tradisional tertua di Indonesia juga telah melakukan transformasi. Perubahan telah menyentuh institusi ini. Pesantren yang pada dasarnya merupakan subkultur dalam kehidupan setelah masyarakat, telah bergeser perannya tidak sekedar lembaga yang mencetak Kiai atau ulama tetapi juga intelektual muslim yang diharapkan dapat melanjutkan cita-cita para pendahulunya untuk memajukan umat Islam secara keseluruhan (Azra, 2001: 27).

Perubahan dimaksud salah satunya dapat kita lihat dari pola hubungan Kiai dan santri yang pada awalnya kita kenal bersifat patron klien yang mengandaikan pola hubungan guru dan murid. Sebagai guru, Kiai tidak hanya dikenal sebagai sosok yang mumpuni dalam ilmu pengetahuan agamanya serta memiliki akhlakul karimah, namun pada sisi yang lain Kiai juga mempunyai pengaruh yang sangat luas di dalam masyarakat melalui karisma yang mereka miliki. Tak pelak, Kiai merupakan figur dambaan umat dan senantiasa mendapat tempat yang mulia dan tinggi dalam struktur masyarakat (Abdullah, 1983: 12).

Sebaliknya, sebagai seorang murid, santri merupakan elemen dalam tradisi pesantren yang kedudukannya lebih rendah dari Kiai. Sebagai pengikut, santri harus senantiasa taat, tawadu dan hormat kepada gurunya. Santri dalam 
kehidupan sehari-harinya harus senantiasa mengikuti apa yang dititahkan oleh seorang Kiai. arus modernisasi telah sedikit banyak membawa pergeseran pada perubahan Kiai dan santri di pesantren sehingga kultur yang selama ini tumbuh subur kemudian mengalami perubahan akibat perkembangan global (Faiqoh, 2003: 25).

Sisi menarik dari model hubungan antara Kiai dengan santri adalah perasaan hormat dan kepatuhan mutlak dari seorang murid kepada gurunya. Perasaan hormat dan kepatuhan mutlak ini tidak boleh terputus, berlaku seumur hidup seorang murid. Perasaan hormat dan kepatuhan mutlak harus ditunjukkan oleh murid dalam seluruh aspek kehidupannya, melupakan ikatan dengan guru merupakan kejelekan dan akan menghilangkan barakah guru dan pada akhirnya ilmu yang dimiliki oleh seorang murid tidak bermanfaat. Hal tersebut dilakukan bukan sebagai manifestasi dari penyerahan total kepada guru yang dianggap memiliki otoritas, tetapi karena keyakinan murid kepada kedudukan guru sebagai penyalur kemurahan Tuhan yang dilimpahkan kepada murid-muridnya, baik di dunia maupun di akhirat. Pola-pola hubungan yang unik antara Kiai dan santri dipengaruhi oleh literatur pendidikan yang dipakai sebagai acuan di pesantren salah satunya adalah kitab Taklim al Mutakalim (Dhofier, 1985: 55).

Sikap hormat takdhim dan kepatuhan kepada Kiai adalah salah satu nilai pertama yang ditanamkan pada setiap santri. Kepatuhan itu mutlak dan diperluas, sehingga mencakup penghormatan kepada para ulama sebelumnya dan ulama yang mengarang kitab-kitab yang dipelajarinya. Kepatuhan ini bagi pengamat luar tampak lebih penting dari pada usaha menguasai ilmu, tetapi bagi Kiai hal itu merupakan bagian integral dari ilmu yang akan dikuasai (Bruinessen, 1995: 18). Problem hubungan antara dunia santri dan Kiai yang sering diklaim sebagai penghambat kemajuan umat adalah berkembangnya budaya patron-klien. "Santri" dipaksa bersikap konservatif dan berfikiran statis, karena alam bawah sadarnya telah terpatri pada ketergantungan Kiai. Para pengasuh pondok harus membuka sekat feodalisme pesantren dengan fikiran demokratis dan kritis para santri. Model itu adalah pembebasan santri untuk bersuara lantang mengkritisi berbagai fenomena dalam masyarakat. Kritik yang diharapkan berkembang dalam budaya santri, menekankan pada keberanian membela kebenaran, rasional, tetap pada kaidah jati diri santri, sekaligus berbasis budaya masyarakat (Dhakiri, 2007: 35)

Perubahan relasi Kiai dengan santri dapat kita lihat dalam ketundukan seorang santri yang mulai berkurang yang diakibatkan oleh bergesernya peran 
Kiai di pesantren maupun masyarakat. Sosok Kiai yang dahulu di segani dan berpengaruh karena memiliki karisma yang jarang dimiliki orang lain, mulai bergeser ketika mereka merambah ke wilayah politik dengan ikut berperan dalam kegiatan politik praktis (Fealy, 2003: 69).

Pada sisi yang lain, seiring dengan demokratisasi di Indonesia dan kesempatan pendidikan yang tinggi oleh santri, banyak komunitas santri yang mulai tercerahkan dimana hal ini bisa kita lihat dari cara berpikir mereka yang kritis, independen dan kreatif. Hal ini tenyata berimbas terhadap hubungan Kiai-santri yang tidak lagi seperti dahulu dimana saat ini santri telah berani mengkritisi apapun yang dilakukan Kiainya yang dianggap melenceng. Karisma yang di anggap sebagai senjata ampuh untuk mempengaruhi santri juga pada tataran tertentu tidak lagi menemukan relevansinya pada saat sekarang. Sehingga praktis, Kiai sekarang sudah mulai kehilangan pengaruhnya akibat dari perannya dalam politik praktis. Konflik Gus Dur dengan Muhaimin dalam tubuh PKB bisa kita analogikan sebagai salah satu contoh melenturnya hubungan Kiai dan santri sebagai akibat ratio excess irratio atau cara berfikir logic dalam kerangka rationalitas menjadi faktor determinan dalam memutuskan segala hal dari pada hubungan kekerabatan (kinship relationship) yang telah lama mengakar dalam kultur pesantren. Mengeroposnya unsur irratio yang dalam beberapa hal mendasari hubungan Kiai-santri ini merupakan sebuah refleksi dari fenomena bahwa hubungan Kiai dan santri saat ini sedang mengalami perubahan.

\section{Eksistensi}

Secara harfiah eksistensi artinya adalah keberadaan. Sesuatu dikatakan eksis bisa dibuktikan dengan dilihat atau dirasakan dengan indra atau juga tidak, tetapi kita bisa melihat bukti-bukti keberadaannya. Misalnya Tuhan tentu saja eksis meskipun kita tidak bisa melihatnya. Tapi kita bisa membuktikan keberadaanya dengan berpikir bagaimana bisa keberadaan segala sesuatu di alam semesta ini, tentu ada "Sesuatu Yang Maha" yang menciptakan dan mengaturnya. Bila dikaitkan dengan eksistensi budaya patron klien dalam pesantren adalah keberadaan Kiai dalam mengasuh para santri.

\section{Budaya}

Budaya atau kebudayaan berasal dari bahasa Sansekerta yaitu buddhayah, yang merupakan bentuk jamak dari buddhi (budi atau akal) diartikan sebagai hal hal yang berkaitan dengan budi dan akal manusia. Dari definisi di atas, 
maka penulis menarik kesimpulan bahwa kebudayaan atau budaya merupakan sebuah sistem, dimana sistem itu terbentuk dari perilaku, baik itu perilaku badan maupun pikiran. Dan hal ini berkaitan erat dengan adanya gerak dari masyarakat, dimana pergerakan yang dinamis dan dalam kurun waktu tertentu akan menghasilkan sebuah tatanan ataupun sistem tersendiri dalam kumpulan masyarakat (Koentjaraningrat, 2000: 181).

\section{Patron Klien}

Istilah "patron" berasal dari ungkapan bahasa Spanyol yang secara etimologis berarti seseorang yang memiliki kekuasaan (power), status, wewenang dan pengaruh. Sedangkan klien berarti "bawahan" atau orang yang di perintah dan yang di suruh. Selanjutnya pola hubungan patron klien merupakan aliansi dari dua kelompok komunitas atau individu yang tidak sederajat. Baik dari segi status, kekuasaan, maupun penghasilan sehingga menempatkan klien dalam kedudukan yang lebih rendah (inferior) dan patron dalam kedudukan yang lebih tinggi (superior). Patron adalah orang yang berada dalam posisi untuk membantu klien-kliennya (Scott, 1983: 14).

\section{Sejarah Pesantren}

Sebelum tahun 60-an, pusat-pusat pendidikan pesantren di Jawa dan Madura dikenal dengan nama pondok. Istilah pondok mungkin berasal dari pengertian asrama-asrama para santri yang disebut pondok atau tempat tinggal yang dibuat dari bambu atau mungkin berasal dari bahasa Arab funduq, yang berarti hotel atau asrama. Secara historis pesantren merupakan lembaga pendidikan Islam yang di kembangkan secara indigenous oleh masyarakat Indonesia. Karena sebenarnya pesantren merupakan produk budaya masyarakat Indonesia yang sadar sepenuhnya akan pentingnya arti sebuah pendidikan bagi orang pribumi yang tumbuh secara natural. Pesantren merupakan institusi pendidikan Islam khas nusantara (Hajar, 2009: 34).

Definisi singkat istilah "pondok" adalah tempat sederhana yang merupakan tempat tinggal Kiai bersama para santrinya (Hasbullah, 1999:142). Di Jawa besarnya pondok tergantung pada jumlah santrinya. Adanya pondok yang sangat kecil dengan jumlah santri kurang dari seratus sampai pondok yang memiliki tanah yang luas dengan jumlah santri lebih dari tiga ribu. Tanpa memperhatikan berapa jumlah santri, asrama santri wanita selalu dipisahkan dengan asrama santri laki-laki. 


\section{Kiai}

Kiai diartikan sebagi figur pemimpin pondok pesantren. Status ini didapat karena keturunan (ascribed status). Penyandangnya adalah seorang keturunan Kiai (anak, saudara kandung, ipar, menantu) yang mempunyai keahlian dalam ilmu agama dan menjadi tokoh masyarakat serta fatwa-fatwanya selalu diperhatikan. Istilah Kiai pada umumnya dipakai oleh masyarakat Jawa untuk menyebut orang lain-bentuk jamak alim dalam bahasa Arab adalah ulama dalam tradisi masyarakat muslim. Kiai biasanya memiliki karisma dan pada umumnya memimpin sebuah pesantren, mengajarkan kitab-kitab klasik (kitab kuning) dan memiliki keterikatan dengan kelompok Islam tradisional (Dhofier, 1985: 55).

Peran penting Kiai dalam pendirian, pertumbuhan, perkembangan dan pengurusan sebuah pesantren berarti dia merupakan unsur yang paling esensial. Sebagai pemimpin pesantren, watak dan keberhasilan pesantren banyak bergantung pada keahlian dan kedalaman ilmu, karismatik dan wibawa, serta ketrampilan Kiai. Dalam konteks ini, pribadi Kiai sangat menentukan sebab dia adalah tokoh sentral dalam pesantren (Hasbullah, 1999: 144).

\section{Santri}

Santri adalah seorang anak atau seorang yang belajar atau menuntut ilmu pada sebuah pondok pesantren atau sebutan bagi para siswa yang belajar mendalami agama di pesantren. Santri merupakan unsur yang penting sekali dalam perkembangan sebuah pesantren karena langkah pertama dalam tahaptahap membangun pesantren adalah bahwa harus ada murid yang datang untuk belajar dari seorang alim. Kalau murid itu sudah menetap di rumah seorang alim, baru seorang alim itu bisa disebut Kiai dan mulai membangun fasilitas yang lebih lengkap untuk pondoknya.

Pada masa lalu kesempatan untuk pergi dan menetap di sebuah pesantren yang jauh merupakan suatu keistimewaan untuk santri karena dia harus penuh cita-cita, memiliki keberanian yang cukup dan siap menghadapi sendiri tantangan yang akan dialaminya di pesantren (Dhofier, 1985:52).

\section{Metode Penelitian}

Jenis penelitian ini adalah penelitian kualitatif dengan menggunakan model studi kasus, penelitian ini tidak ditujukan untuk menguji hipotesa oleh karena itu tidak menerapkan metode penghitungan statistik kuantitatif. Sebagai penelitian studi kasus, maka langkah-langkah yang akan ditempuh 
dalam penelitian ini adalah sebagai berikut: melakukan pengumpulan data pada kasus pertama, yaitu Pesantren Daarul Fikri Mulyoagung Dau Malang. Penelitian ini dilakukan sampai pada tingkat kejenuhan data dan selama itu pula dilakukan kategorisasi dalam tema-tema untuk menemukan konsepsi tematik mengenai budaya patron klien di pesantren tersebut.

Lokasi penelitian terletak di Pondok Pesantren Daarul Fikri Mulyoagung Dau Malang. Dengan pertimbangan Pesantren Daarul Fikri merupakan suatu lembaga independen yang tidak berafiliasi kepada organisasi atau golongan manapun. Hal ini menjadikan Daarul Fikri sebagai lembaga pendidikan yang mengedepankan kemurnian dan idealisme pendidikan yang terbebas dari kepentingan politik maupun golongan tertentu.

Peneliti memilih informasi yang dipandang paling mengetahui masalah yang dikaji. Penentuan informan dilakukan secara snowball. Key informan dalam penelitian ini adalah para Kiai maupun santri yang ada di Pondok Pesantren Daarul Fikri Mulyoagung Dau Malang. Penambahan dan wawancara dengan informan dilakukan hingga data yang didapat mencapai kejenuhan teoritik atau informasi yang diperoleh sama antara informan-informan yang diwawancarai (Moleong, 2007: 23).

Purposive sampling adalah teknik penentuan sampel untuk tujuan tertentu saja. Sampel yang dipilih adalah orang yang ahli dalam bidang keagamaan saja. Snowball sampling adalah teknik penentuan sampel yang mula-mula jumlahnya kecil, kemudian sampel ini disuruh memilih teman-temannya untuk dijadikan sampel. Begitu seterusnya, sehingga jumlah sampel semakin banyak (Sugiyono, 2009: 72).

Teknik pengumpulan data menggunakan observasi partisipatif, wawancara mendalam, studi dokumenter, proses analisis data dimulai dengan menelaah seluruh data yang tersedia dari berbagai sumber, yaitu wawancara, pengamatan, yang sudah ditulis dalam catatan lapangan, dokumen pribadi, dokumen resmi, gambar foto, dan sebagainya, langkah berikutnya adalah mengadakan reduksi data yang dilakukan dengan jalan membuat abstraksi (Milles, 1992: 82).

\section{Hasil dan Pembahasan}

\section{Pola Interaksi Hubungan Sosial Kiai dan Santri}

Pada pondok pesantren modern sebagai institusi pendidikan, terjadi pola interaksi Kiai dan santri yang unik yang membedakannya dengan institusi pendidikan yang lain. Hubungan yang dibentuk antara Kiai dengan santri adalah bentuk hubungan guru dan murid yang terlihat dalam hubungan bapak 
dan anak dan juga patron klien. Kiai sebagai patron adalah Kiai yang mampu membangun sebuah patronase dengan santrinya melalui ikatan emosional yang kuat. Patron memberikan jasa kepada santri baik pengetahuan, material dan harapan barakah serta ilmu bermanfaat. Dalam konteks kesantrian tidak ada harga yang mampu ditebus untuk membayar segala pengetahuan yang diberikan oleh Kiainya. Oleh sebab itu santri sebagai klien harus memperlihatkan tandatanda ketakdhiman terhadap Kiainya.

Model hubungan Kiai-santri di Pesantren Daarul Fikri ada dua tipe: (1) pola hubungan guru dan murid adalah hubungan yang terjalin antara Kiai dan santri sebagaimana layaknya antara guru dengan murid dalam pola hubungan formal, (2) pola hubungan bapak-anak, yaitu pola hubungan yang terjalin antara Kiai dengan santrinya sebagaimana layaknya antara bapak dengan anak. Dalam pandangan Kiai, santri disamping sebagai anak didiknya juga dianggap sebagai bagian dari keluarganya. Tindakan ini mendorong terbentuknya pola hubungan yang terjalin antara Kiai dengan santri sebagaimana layaknya hubungan antara bapak dan anak (pola paternalisme).

Pola hubungan paternalisme yang terjalin antara Kiai dan santri di pesantren di pengaruhi oleh faktor intern dan ekstern. Faktor intern adalah faktor yang berasal dari diri Kiai yang bersangkutan yang memandang santri sebagai amanat yang harus dididik sebagaimana anaknya sendiri. Sedangkan faktor ekstern berasal dari tradisi orang tua santri yang menyerahkan anaknya kepada Kiai secara langsung dan santri yang menganggap Kiai sebagaimana orang tuanya sendiri di pesantren.

Pada Pondok Pesantren Daarul Fikri, menurut Kiai Sumhudi terjadi kesepakatan antara orang tua calon santri dengan Kiai pondok pesantren mengenai penyerahan wewenang mendidik santri dari orang tua kepada Kiai. Orang tua memberi amanah kepada Kiai untuk mendidik anaknya, sebab keterbatasan mereka. Dalam penyerahan tersebut, kesepakatan yang terjadi diantara keduanya, jika dituliskan dalam bahasa Jawa, yaitu, "kulo selaku wali santri masrahaken dumateng panjenengan Pak Kiai, supados ndidik anak kulo teng pondok niki amargi bloko suto kulo mboten ngertos babakan agami suci. " (arti dalam bahasa Indonesia yaitu, saya selaku wali santri "memberikan wewenang" kepada Pak Kiai, agar mendidik anak saya di dalam pondok pesantren ini karena saya sama sekali tidak tau masalah agama).

Kata, "masrahake", yang berarti, "memberikan suatu wewenang kepada Kiai", menurut Kiai Sumhudi, tidak sekedar menitipkan suatu barang, dimana pihak yang dititipi tidak mempunyai kuasa atau hak terhadap barang tersebut, tetapi 
pihak yang diberi wewenang (dalam bahasa Jawa, "dipasrahi") mempunyai hak untuk mendidik dan mengatur perilaku atau langkah hidup anak yang diserahkan tersebut. Akan tetapi, dibalik itu ada kewajiban yang harus dipikul Kiai dalam hubungannya dengan orang tua maupun kepada Tuhan Yang Maha Esa. Kiai merasa bertanggung-jawab atas keberhasilan pendidikan santri-santri mereka dihadapan wali santri dengan dibuktikan melalui perubahan tingkah laku yang telah terjadi (Wawancara dengan informan, 17 juni 2010)

Nilai-nilai yang terdapat di pondok pesantren mengandung tiga unsur yang mengarah pada terbentuknya hubungan patron klien antara Kiai dan santri, yaitu: (1) Hubungan patron klien mendasarkan diri pada pertukaran yang tidak seimbang yang mencerminkan perbedaan status. Seorang klien, dalam hal ini santri telah menerima banyak jasa dari patron dalam hal ini Kiai, sehingga klien terikat dan tergantung pada patron, (2) Hubungan patron klien bersifat personal. Pola resiprositas yang personal antara Kiai dan santri menciptakan rasa kepercayaan dan ketergantungan di dalam mekanisme hubungan tersebut. Hal ini dapat di lihat pada budaya penghormatan santri ke Kiai yang cenderung bersifat kultus individu, (3) Hubungan patron tersebar menyeluruh, fleksibel dan tanpa batas kurun waktunya. Hal ini dimungkinkan karena sosialisasi nilai ketika menjadi santri berjalan bertahun-tahun. Suatu bentuk nilai yang senantiasa dipegang teguh santri, misalnya tidak adanya keberanian santri berdebat soal apa pun dengan Kiai atau membantahnya karena bisa kualat dan ilmunya tidak bermanfaat. Suatu kutukan dirasa berat, bila sampai dilontarkan Kiai kepada santri (Mas'ud, 2004:84).

Dari penjelasan ini, dapat di ambil pengertian bahwa santri mengakui dan menerima sumber-sumber yang dimiliki Kiainya, sehingga kalau patron mempengaruhi klien, maka klien menerima dan mengakui pengaruh tersebut secara sadar atau sukarela. Sumber yang dimaksud dapat berupa tata nilai, struktur organisasi dan kekuasaan Kiai. Kemampuan Kiai menduduki posisi patron karena memiliki sumber-sumber yang tidak di miliki oleh orang yang dipengaruhi atau yang dikuasainya (klien).

Ketiga faktor yang mendasari patron klien di pondok pesantren sudah barang tentu terlihat pada tipe kepemimpinan yang dijalankan dalam mengelola lembaga pondok pesantren. Dengan penonjolan dominasi Kiai (keluarga Kiai) dan penekanan kuat tradisi, akhirnya kepemimpinan yang muncul bercorak paternalistik di mana seorang Kiai berstatus sebagai pelindung, guru dan bapak. Artinya kebersamaan para anggota, posisinya sebagai bawahan dalam pondok pesantren, sedangkan pemimpin berada di atas para anggota tersebut. 


\section{Perubahan Pola Interaksi Hubungan Sosial antara Kiai dan Santri}

Secara lebih khusus perubahan pandangan mengenai tradisi pesantren modern ini, haruslah kita lihat dari perubahan pandangan pengasuh Pondok Pesantren Daarul Fikri terhadap pendidikan pesantren modern, sebab langkah diversifikasi program pendidikan yang mereka ambil, menyangkut pula perubahan pandangan Kiai yang hirarkis menuju ke arah yang egaliter dalam hubungannnya dengan interaksi Kiai dengan santri. Kalau sebelum tahun 2001, pengasuh pondok ini terhitung orang yang menganut tradisi salafiyah, kini pihak pengasuh berpandangan berimbang antara pendidikan agama dan pendidikan umum, ketimbang bersikukuh mempertahankan ketakutan dirinya akan hadirnya pendidikan umum/modern dan rusaknya tradisi salafiyah. Tidak dapat dipungkiri, jika pendidikan modern yang dibawa dan diakses santri-santri Pondok Pesantren Daarul Fikri berakibat besar terhadap perubahan pola interaksi santri terhadap Kiainya.

Persentuhan pondok pesantren dengan sekolah atau madrasah atau istilah sekarang pondok pesantren modern, menuntut para pengelola pesantren untuk melakukan berbagai perubahan dan penyempurnaan. Baik perubahan perangkat keras maupun perangkat lunak (hard ware and soft ware). Akibat dari persentuhan itu, kondisi pondok pesantren menjadi berubah segalanya. Dulu bangunan sederhana, bangunan tua yang terbuat dari kayu dan bambu kini disulap menjadi gedung megah, permanen karena dibangun dengan biaya cukup besar. Sekalipun dana yang tersedia tidak mencukupi untuk keperluan itu, namun ada upaya lain dalam menutupi kekurangannya dengan menarik infaq dari para orangtua siswa/santri mereka.

Pendidikan modern merupakan suatu bekal bagi santri untuk hidup di dunia dimana keberhasilan hidup di dunia akan menunjang untuk hidup di akhirat. Menelan pendidikan modern tanpa diimbangi oleh pendidikan agama, berarti ingin melahirkan orang-orang yang berintelektual tinggi tetapi moralitasnya masih dipertanyakan. Kiai Sumhudi sadar betul bahwa paradigma pendidikan modern lebih bertendensi pada ranah kognitif yang mengabaikan nilai-nilai masyarakat dan Islam. Untuk itu fungsi pendidikan agama adalah sebagai pengendali nafsu manusia sehingga dapat berperilaku sesuai dengan ketetapan dan aturan yang ada. Pendidikan agama yang dapat membentuk manusia yang berakhlak mulia salah satunya dapat ditempuh melalui pendidikan pondok pesantren. Melalui pendidikan agama dan pendidikan modern yang murah dan mudah diakses akan membekali santri kompetensi yang integral dan komprehensif. Oleh karena alasan ini Kiai Sumhudi menyarankan kepada 
santri-santrinya agar tidak hanya mengenyam pendidikan agama saja tetapi mengakses pendidikan modern yang telah tersedia baik di kompleks pondok pesantren maupun di luar kompleks pondok pesantren.

Kalau dahulu sebelum tahun 2001, Kiai Sumhudi termasuk orang yang sulit untuk diajak mengikuti perkembangan zaman tetapi kini ia adalah salah satu orang yang militan dalam memperjuangkan keseimbangan antara pendidikan agama dengan pendidikan modern kepada santri-santrinya. Ia berpandangan bahwa kedua ilmu yang didapat baik itu dari pendidikan agama maupun pendidikan modern haruslah seimbang. Hilang salah satu diantara keduanya adalah suatu kepincangan, sebab santri-santri yang dia asuh adalah orang-orang yang hidup di alam masa kini dengan perubahan pola pikir masyarakat yang begitu cepat.

Perubahan ini juga berpengaruh besar terhadap relasi Kiai dengan masyarakat maupun santri mereka. Relasi sosial antara Kiai-santri dibangun atas dasar kepercayaan bukan karena patron klien, sebagaimana yang dilakukan masyarakat pada umumnya. Kalau dahulu ketaatan santri dibangun karena sejumlah harapan mendapatkan barakah dan menghindari kualat dari Kiainya, kini hubungan yang dibentuk bukanlah suatu ketakutan, melainkan sewajarnya menghormati orang yang mempunyai ilmu lebih tinggi (Wawancara dengan santri, 20 juni 2010).

\section{Faktor-Faktor yang Menyebabkan Budaya Patron Klien Dapat Bertahan Sampai Sekarang}

\section{a. Kepemimpinan Karismatik}

Biar bagaimanapun, seorang Kiai adalah sosok ideal dimata santrisantrinya. Ia dianggap sebagai seseorang yang konsisten dalam pengamalan ajaran Islam yang telah ia sampaikan kepada santri-santrinya. Kiai sebagai sosok yang ideal dimata santri mereka adalah sosok yang perlu untuk ditauladani oleh segenap santri. Santri menganggap Kiai sebagai sosok yang diidolakan, dicintai, bahkan ditakuti sebab Kiai adalah pewaris ajaran dan perilaku Nabi. Patuh terhadap Kiai dan seperangkat nilai-nilai yang telah dilembagakan pada pondok pesantren berarti itulah kepribadian menjadi seorang muslim yang sejati. Akibatnya santri harus tunduk kepada Kiainya dengan jalan patuh terhadap aturan pondok pesantren dan kebijakan/perintah yang diberikan kepada santrinya. Dalam diri santri terdapat rasa hormat dan kepatuhan yang tinggi, hal ini karena pada dasarnya untuk mendapatkan ilmu dari Kiai maka seorang santri memiliki rasa rendah hati dan lapang dada. Hal semacam ini mengacu 
pada sebuah kitab klasik Taklimul Mutakalim, tertulis sebagai berikut:

"Mereka yang mencari pengetahuan hendaklah mereka ingat bahwa tidak akan pernah mendapatkan pengetahuan atau pengetahuannya tidak akan berguna, kecuali dia menaruh hormat pada pengetahuannya tersebut, dan juga menaruh hormat kepada Kiai yang telah mengajarnya.

Dapat dipahami bahwa munculnya bentuk kepemimpinan karismatik seringkali mengabaikan nilai-nilai demokratis sebab kepemimpinan tersebut tidak rasional. Segala perintah yang diberikan kepada warga pesantren tradisional terutama santrinya, hampir mutlak dikerjakan selagi tidak bertentangan dengan syariat Islam. Seringkali santri tidak menyadari apa tujuan tersirat dibalik suatu perintah itu tetapi mereka meyakini bahwa perintah seorang Kiai adalah benar dan bertujuan baik bagi dirinya. Santri yakin sekali bahwa dibalik perintah orang suci itu terdapat suatu "barakah" jika dilaksanakan tetapi tidak patuh terhadap Kiai berarti ingin mendapatkan "kualat". Bentuk interaksi seperti ini menutup celah bagi seorang santri untuk melakukan kritik apalagi melawan terhadap gurunya.

\section{b. Barakah dan Kualat: Landasan Spiritual Realitas Sosial Kiai}

Ikatan guru dengan murid yang berarti ikatan Kiai dan santri sampai kapanpun status tersebut masih berlaku meskipun si santri tidak lagi belajar di Kiai tersebut. Pengucapan sebutan bekas terhadap seorang guru seringkali dianggap sebagai hal yang hina yang tidak diperkenankan. Sampai kapanpun santri adalah murid Kiai. Santri yakin jika melanggar aturan seperti ini berarti ia ingin mendapatkan "kualat" hidupnya serba tidak barakah.

Seorang santri jika tidak ingin mendapatkan kualat karena berbuat tidak bijak terhadap gurunya maka ia harus melakukan penyerahan total dalam artian tunduk kepada gurunya asalkan tidak melakukan perintah yang bertentangan dengan syariat Islam. Meskipun seorang guru tidak tahu kalau muridnya telah melakukan tindakan yang lancang tetapi kualat akan diturunkan oleh Tuhan. Ini semua karena guru adalah orang yang dekat dengan Tuhan dan atas seizinNya apapun dapat menimpa terhadap murid jika melawan terhadap gurunya dan atas seizin Tuhan pula sang guru dapat menyalurkan kemurahan dari Tuhan.

Menurut Kiai Sumhudi dari Pondok Pesantren Daarul Fikri dekat dengan guru berarti kita dekat dengan malaikat yang berarti pula kita dekat dengan Allah. Mendapatkan ridho guru, diyakininya pasti akan mendapatkan ridho dari Allah. Oleh sebab itu ilmu yang bermanfaat mengandung maksud, ilmu yang mendapatkan barakah dari guru yang berarti juga mendapatkan 
barakah dari Allah sehingga dapat disebarluaskan dan mendatangkan pahala (aspek ibadah). Secara teoritis penyaluran barakah tersebut di atas, terkait erat dengan pancaran cahaya Allah yang membekas pada Kiai kemudian menyalur ke santri.

\section{c. Ikatan Seumur Hidup antara Kiai dengan Santri}

Ikatan emosi antara santri dengan Kiainya sedikit banyak telah mampu menyangga kehidupan perekonomian pesantren. Dari kalangan santri sering kali memberikan sumbangan kepada pesantrennya dalam bentuk material apapun. Demikian juga para alumni yang masih aktif bersilaturahmi terhadap Kiainya juga sering memberikan sejumlah material tertentu. Ada 2 (dua) faktor yang terus melanggengkan hubungan antara Kiai dan santri.

Faktor pertama, ia melihat relasi tersebut dari segi kebudayaannya. Ia mengemukakan bahwa hubungan antara Kiai dan santrinya sangat dekat dan dalam banyak kasus, sangat emosional karena posisi karismatik Kiai dalam masyarakatnya dikuatkan oleh budaya subordinasi. Hubungan dekat ini tidak hanya terbatas selama di pesantren tetapi terus berlangsung setelah santri menjadi anggota masyarakat maka penyebaran dan kesinambungan budaya seperti itu semakin terjamin. Hubungan tidak setara ini terus terpelihara karena mantan santri terus mengunjungi Kiainya secara rutin. Alumni sebuah pesantren biasanya melakukan kunjungan rutin kepada Kiainya hanya untuk bersilaturahmi dan memperoleh karunianya. Kunjungan rutin seperti itu tidak berhenti bahkan setelah anak Kiai menggantikan ayahnya sebagai pemimpin baru pesantren. Ini karena posisi Kiai dan anaknya adalah sama dalam pandangan santri. Selain itu, pada saat anak tersebut menjadi Kiai, dengan menggantikan ayahnya maka mantan santri terdahulu biasanya mengirim anak-anaknya ke pesantren yang sekarang di kelola oleh anak Kiai tadi.

Faktor kedua yang mengikat santri dengan Kiainya terkait dengan ritual ritual keagamaan tertentu yang diadakan oleh Kiai dan dihadiri oleh mantan santri termasuk mereka dari daerah lain. Ritual ritual ini beragam bentuknya mulai dari peringatan wafatnya pendiri pesantren hingga festival pada akhir masa pembelajaran. Dalam dunia tarekat ada ritual ritual keagamaan seperti "mujadahan kubro" yang dihadiri oleh ribuan pengikutnya. Di satu sisi ritual ritual itu menyediakan forum dimana orang-orang dapat mengamalkan keyakinan-keyakinan keagamaan mereka tapi di sisi lain, ia juga menjadi medium dimana hubungan antara Kiai dan santrinya atau pengikutnya dapat terus diperkuat. 
Kuatnya ikatan emosional antara Kiai dengan santri telah menyebabkan hubungan diantara keduanya berlangsung selama hidup. Sampai kapanpun santri adalah murid dari Kiainya. Meskipun santri telah lulus dan kembali ke masyarakat ataupun Kiai mereka telah wafat, ada kewajiban moral untuk mendoakannya melalui ziarah kubur, seperti dalam acara chaul. Ada 2 (dua) hal yang melanggengkan hubungan Kiai santri, yaitu budaya subordinasi yang berkesinambungan dan ritual ritual yang diselenggarakan oleh pondok pesantren. Budaya subordinasi menurutnya mengandung maksud hubungan yang tidak setara antara guru dan murid yang kemudian dilestarikan hingga si santri mempunyai anak-anak dan kemudian anak-anak tersebut di pondokkan di pesantren yang sama sehingga menjadi murid Kiai yang bersangkutan. Sedangkan ritual ritual yang diadakan di pondok seperti chaul, akhirussanah dan silaturahmi lebaran yang seringkali mengundang dan dihadiri oleh santrisantri alumni ikut pula mempererat hubungan Kiai dan santri tersebut.

\section{Simpulan}

Model hubungan Kiai dan santri di Pesantren Daarul Fikri ada dua tipe: pertama, pola hubungan guru-murid adalah hubungan yang terjalin antara Kiai dan santri sebagaimana layaknya antara guru dengan murid dalam pola hubungan formal. Kedua, pola hubungan bapak dan anak, yaitu pola hubungan yang terjalin antara Kiai dengan santrinya sebagaimana layaknya antara bapak dengan anak. Pola hubungan paternalisme yang terjalin antara Kiai dan santri di pesantren di pengaruhi oleh faktor intern dan ekstern. Faktor intern adalah faktor yang berasal dari diri Kiai yang bersangkutan yang memandang santri sebagai amanat yang harus dididiknya sebagaimana anaknya sendiri. Sedangkan faktor ekstern berasal dari tradisi orang tua santri yang menyerahkan anaknya kepada Kiai secara langsung dan santri yang menganggap Kiai sebagaimana orang tuanya sendiri di pesantren.

Perkembangan Pondok Pesantren Daarul Fikri ke arah modernisasi bukanlah suatu hal yang dirasa tidak akan menimbulkan suatu kekhawatiran pihak Kiai. Tidak dapat dipungkiri, jika pendidikan modern yang dibawa dan diakses santri-santri Pondok Pesantren Daarul Fikri berakibat besar terhadap perubahan pola interaksi santri terhadap Kiainya, sistem pendidikan, pola hidup santri, maupun kondisi pesantren. Dahulu ketaatan santri dibangun karena sejumlah harapan mendapatkan barakah dan menghindari kualat dari Kiainya, kini hubungan yang dibentuk bukanlah suatu ketakutan, melainkan sewajarnya menghormati orang yang mempunyai ilmu lebih tinggi. 
Faktor yang menyebabkan budaya patron klien dapat bertahan sampai sekarang antara lain: Kepemimpinan karismatik Kiai, nilai barakah dan nilai kualat: landasan spiritual realitas sosial Kiai, ikatan seumur hidup antara Kiai dengan santri. Faktor pertama, ia melihat relasi tersebut dari segi kebudayaannya. Ia mengemukakan bahwa hubungan antara Kiai dan santrinya sangat dekat dan dalam banyak kasus, sangat emosional karena posisi karismatik Kiai dalam masyarakatnya dikuatkan oleh budaya subordinasi. Hubungan dekat ini tidak hanya terbatas selama di pesantren tetapi terus berlangsung setelah santri menjadi anggota masyarakat maka penyebaran dan kesinambungan budaya seperti itu semakin terjamin. Hubungan tidak setara ini terus terperlihara karena mantan santri terus mengunjungi Kiainya secara rutin. Alumni sebuah pesantren biasanya melakukan kunjungan rutin kepada Kiainya hanya untuk bersilaturahmi dan memperoleh karunianya. Faktor kedua yang mengikat santri dengan Kiainya terkait dengan ritual ritual keagamaan tertentu yang diadakan oleh Kiai dan dihadiri oleh mantan santri termasuk mereka dari daerah lain. Ritual ritual ini beragam bentuknya mulai dari peringatan wafatnya pendiri pesantren hingga festival pada akhir masa pembelajaran. Dalam dunia tarekat ada ritual ritual keagamaan seperti "mujadahan kubro" yang dihadiri oleh ribuan pengikutnya. Di satu sisi ritual ritual itu menyediakan forum dimana orang-orang dapat mengamalkan keyakinan-keyakinan keagamaan mereka tapi di sisi lain, ia juga menjadi medium dimana hubungan antara Kiai dan santrinya atau pengikutnya dapat terus diperkuat.

\section{Daftar Pustaka}

Abdullah, Taufik. 1983. Agama dan Perubahan Sosial. Jakarta: CV Rajawali.

Azra, Azyumardi. 2001. Pendidikan Islam: Tradisi dan Modernisasi Menuju Milenium Baru. Jakarta: Penerbit Kalimah.

Bruinessen, Martin Van, 1995. NU, Tradisi, Relasi Kuasa, Pencarian Wahana Baru. Yogyakarta: LKIS.

Dhakiri, Hanif. 2007. Kiai Kampung Dan Demokrasi Lokal. Jakarta: Dewan Pengurus Pusat Partai Kebangkitan Bangsa (DPP PKB) Dengan Yayasan Kajian dan Layanan Informasi Untuk Kedaulatan Rakyat.

Dhofier, Zamakhsyari. 1985. Tradisi Pesantren: Studi Tentang Pandangan Hidup Kiai, Jakarta: LP3ES. 
Faiqoh. 2003. Nyai Agen Perubahan di Pesantren. Jakarta: Kucica.

Fealy, Greg. 2003. Ijtihad Politik Ulama: Sejarah NU 1952-1967. Yogyakarta: LKiS.

Hajar, Ibnuu. 2009. Kiai di tengah pusaran politik. Yogyakarta: IRCiSoD.

Hasbullah. 1999. Sejarah Pendidikan Islam di Indonesia: Lintasan Sejarah Pertumbuhan dan Perkembangan. Jakarta: PT Raja Grafindo Persada.

Koentjaraningrat. 2000. Pengantar IImu Antropologi. Jakarta: Radar Jaya Offset.

Mas'ud, Abdurrahman. 2004. Intelektual Pesantren Perhelatan Agama dan Tradisi. Yogyakarta: LkiS.

Milles, Matthew B. \& A. Michael Huberman. 1992. Analisis Data Kualitatif. Diterjemahkan oleh Tjetjep Rohendi Rohidi. Jakarta: Universitas Indonesia Press.

Moleong, Lexy J. 2007. Metodologi Penelitian Kualitatif: Bandung: Rosdakarya.

Scott, James C. 1983. Moral Ekonomi Petani. Jakarta: LP3S.

Sugiyono. 2009. Metode Penelitian Kuantitatif Kualitatif. Bandung: Alfabeta.

Sutrisno, Hadi. 2004. Metodologi Research. Yogyakarta: Penerbit Andi. 